\title{
Cooperative behavior and management of a patient care team in an oncohematology hospital service
}

\author{
Comportamento cooperativo e gestão da equipe de assistência ao paciente em serviço hospitalar de oncohematologia
}

Comportamiento cooperativo y gestión del equipo de atención al paciente en un servicio hospitalario de oncohematología

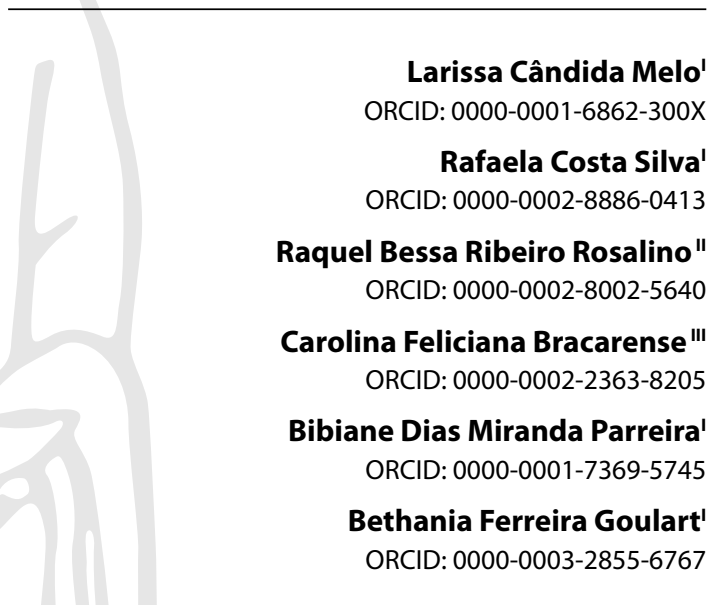

'Universidade Federal do Triângulo Mineiro. Uberaba, Minas Gerais, Brazil.

"Universidade Federal do Triângulo Mineiro, Hospital de Clínicas. Uberaba, Minas Gerais, Brazil.

III Prefeitura Municipal de Uberaba, Secretaria Municipal de Saúde. Uberaba, Minas Gerais, Brazil.

How to cite this article: Melo LC, Silva RC, Rosalino RBR, Bracarense CF, Parreira BDM, Goulart BF. Cooperative behavior and management of a patient care team in an oncohematology hospital service. Rev Bras Enferm. 2021;74(4):e20201169. https://doi.org/10.1590/0034-7167-2020-1169

Corresponding author: Bethania Ferreira Goulart E-mail: bethaniagoulart@yahoo.com.br

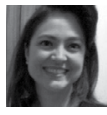

EDITOR IN CHIEF: Antonio José de Almeida Filho ASSOCIATE EDITOR: Ana Fátima Fernandes

Submission: 11-19-2020

Approval: 02-09-2021

\begin{abstract}
Objective: to identify the perceptions of teamwork according to professionals of an oncohematology unit. Methods: this is an exploratory study/qualitative approach. Nineteen health professionals from the oncohematology unit of a public teaching hospital participated. Data collection took place through semi-structured interviews, from September to December 2018. Data analysis followed Content Analysis, thematic modality, and the work process theoretical framework. Results: two categories emerged: Cooperative behavior of professionals from an oncohematology unit, revealing meanings of teamwork and its facilitating/hindering factors in the unit, and Composition, characteristics and management of the unit, presenting teamwork in the perspective of organization/dynamics of work at the unit, material instruments, qualification/training, team composition and organizational management. Final considerations: there is a need for management to know and better understand the work of workers and their difficulties, providing psychological support to the team. Descriptors: Patient Care Team; Interprofessional Relations; Cooperative Behavior; Health Communication; Oncology Service, Hospital.
\end{abstract}

\section{RESUMO}

Objetivo: identificar as percepções do trabalho em equipe segundo os profissionais de uma unidade de oncohematologia. Métodos: estudo exploratório/abordagem qualitativa. Participaram 19 profissionais de saúde da unidade de oncohematologia de um hospital público de ensino. A coleta de dados ocorreu por meio de entrevistas semiestruturadas, de setembro a dezembro de 2018. Análise de dados seguiu a Análise de Conteúdo, modalidade temática, e o referencial teórico de processo de trabalho. Resultados: emergiram duas categorias temáticas: Comportamento cooperativo dos profissionais da unidade de oncohematologia, revelando significados do trabalho em equipe e seus fatores facilitadores/dificultadores na unidade, e Composição, características e gestão da unidade, apresentando o trabalho em equipe na perspectiva da organização/dinâmica do trabalho na unidade, instrumentos materiais, capacitação/treinamento, composição da equipe e gestão organizacional. Considerações finais: destaca-se necessidade de a gestão conhecer e entender melhor o trabalho dos agentes e suas dificuldades, disponibilizando o amparo psicológico à equipe.

Descritores: Equipe de Assistência ao Paciente; Relações Interprofissionais; Comportamento Cooperativo; Comunicação em Saúde; Serviço Hospitalar de Oncologia.

\section{RESUMEN}

Objetivo: identificar las percepciones del trabajo en equipo según los profesionales de una unidad de oncohematología. Métodos: estudio exploratorio/abordaje cualitativo. Participaron 19 profesionales de la salud de la unidad de oncohematología de un hospital universitario público. La recolección de datos se realizó a través de entrevistas semiestructuradas, de septiembre a diciembre de 2018. El análisis de los datos siguió el Análisis de Contenido, la modalidad temática y el marco teórico del proceso de trabajo. Resultados: surgieron dos categorías temáticas: Comportamiento cooperativo de los profesionales de la unidad de oncohematología, revelando significados del trabajo en equipo y sus factores facilitadores/obstaculizadores en la unidad, y Composición, características y gestión de la unidad, presentando el trabajo en equipo en la perspectiva de la organización/dinámica. de trabajo en la unidad, instrumentos materiales, cualificación/formación, composición del equipo y gestión organizativa. Consideraciones finales: existe la necesidad de que la gerencia comprenda y comprenda mejor el trabajo de los agentes y sus dificultades, brindando apoyo psicológico al equipo.

Descriptores: Grupo de Atención al Paciente; Relaciones Interprofesionales; Conducta Cooperativa; Comunicación en Salud; Servicio de Oncología en Hospital. 


\section{INTRODUCTION}

The health work process presupposes social relationships, incorporating needs that encompass health professionals, managers and patients, which are determined by working conditions and human factors that influence the provision of services ${ }^{(1)}$.

In hospitals, there are several conflicting situations that weaken interprofessional relationships. This process requires management's attention, as the environment can cause dissatisfaction and even a deficit of assistance ${ }^{(2)}$. The aforementioned work routine points to the need for action that promotes open and effective interprofessional communication, the strengthening of teamwork, collaboration and co-responsibility for safe assistance ${ }^{(1)}$, whereas the provision of safe and quality care depends on teamwork and collaboration $^{(3)}$ between workers.

In view of an oncology unit, this attention must occur in an even more special way, since the clientele requires assistance that demands excessive emotional burden; consequently, professionals tend to live in a more tasteless work environment ${ }^{(4)}$. From this perspective, especially in the care of critically ill patients, the importance of professionals to act effectively as a team ${ }^{(5)}$ stands out, a fundamental aspect for quality treatment of cancer patients $s^{(6)}$, generating benefits for them ${ }^{(7)}$.

It becomes opportune to draw attention to teamwork as a tool that enables articulated collective work, based on assistance beyond the sum of disjointed techniques and procedures, understanding that such assumptions are in line with what the unit of oncohematology requires.

Gaps in scientific production are evident regarding teamwork in the scenario in focus in this study. Oncohematology units have their particularities and specificities, as professionals live with critically ill patients, with the anguish of family members and the proximity to death, aspects that can result in suffering and overload for team workers. Workers provide qualified technical assistance, but they may have difficulties in carrying out more collective and articulated work, often presenting limitations in interacting with each other and acting collaboratively. Despite the fact that the unit is a closed environment, which generates more time among professionals, this alone is not enough to ensure teamwork. Bringing up the perceptions of oncohematology professionals about their own work and the perspective of collective work may generate subsidies for the performance of management in promoting more integrated work in this peculiar scenario. In view of this, the question is: what do oncohematology professionals think and how do they perceive teamwork in that context?

\section{OBJECTIVE}

To identify the perceptions of teamwork according to professionals of an oncohematology unit.

\section{METHODS}

\section{Ethical aspects}

This study is part of a larger project entitled "Trabalho em equipe em unidades hospitalares: facilidades e dificuldades". In compliance with Resolution 466/2012 of the Brazilian National Health Council (Conselho Nacional de Saúde), the project was approved by the Research Ethics Committee (REC) involving human beings from Universidade Federal do Triângulo Mineiro (UFTM) via Plataforma Brasil (Brazil Platform). Research participants signed the Informed Consent Form (ICF), ensuring confidentiality and privacy.

\section{Theoretical-methodological framework}

The work process ${ }^{(8)}$ in health was used as a theoretical framework, building a dialogue between the findings regarding teamwork and the components of the work process, in the perspective of articulating theoretical concepts with the experience of professionals in a oncohematology unit and to promote discussions aimed at contributing reciprocally to the transformation of work objects and workers themselves.

The work process is the arrangement of the elements: work object, instruments, purpose and workers. An object is understood as that which will be modified by workers. In this study, therefore, the object is about health conditions. To transform the object, workers, in this case, health professionals, use material instruments, such as equipment, medicines and non-materials, such as knowledge and knowledge, with the purpose of reaching the pre-established purpose: integral restoration of health ${ }^{(8)}$.

\section{Type of study}

An exploratory study was carried out, with a qualitative approach, following the criteria of the COnsolidated criteria for REporting Qualitative research (COREQ). COREQ is subdivided into three domains (research and reflexivity team, study design and analysis/results) and aims to direct important aspects of the research, ensuring reliability. This approach makes it possible to understand situations through empirical behaviors, capturing the essence of what is being investigated, not depending on the frequency in which it appears, but rather on the verified importance $^{(9)}$.

\section{Study setting}

The oncohematology unit, in the focus of this study, has seven active beds and is part of a public, teaching hospital, at a tertiary level, which includes 302 beds, in a city in the countryside of Minas Gerais, a reference for care of high technological density.

\section{Data source}

The oncohematology unit, at the time of data collection, had 27 health professionals directly linked to assistance, including nine nursing technicians, seven nurses, five doctors, two psychologists, a physiotherapist, a social worker, a dentist and a nutritionist.

Of the total of 27 professionals, 19 professionals from the health team were interviewed by intentional choice, distributed among seven nursing technicians (36.84\%), six nurses (31.57\%), four doctors (21.05\%), a physiotherapist (5.27\%) and a dentist (5.27\%). Participants were those who met the inclusion criteria, which consisted of working at the unit for at least one year. Those 
who were away from work at the time of data collection, those who refused to participate and those not located, after three attempts, were excluded for scheduling the interview.

Eight professionals did not participate, as four had left/been transferred/dismissed from work at the time of data collection, two had less than a year of work in the unit, one was not found after three attempts to schedule the interview and one was refused to participate.

\section{Data collection and organization}

Data collection took place from September to December 2018, through semi-structured interviews, and applied by two undergraduate nursing students, who were properly trained by the research coordinator. Each interviewer introduced himself to the professional invited to participate, one-to-one, explained the project, the justification for conducting the study and the interview technique. The interview was guided by a script developed by the researchers themselves, which was submitted to apparent and content validation by three doctors on the theme and/or on the research methodology adopted. The script was divided into two parts: the first is related to participants' sociodemographic and professional data; the second part contemplated the guiding questions to investigate, from professionals' point of view, how work was carried out and what were the perceptions regarding teamwork in that scenario. A pilot test was carried out with professionals from another sector of the hospital before definitive data collection. The interviews were conducted face to face, audio recorded during the shift, at a time indicated by the participant, in a private room in the oncohematology unit, with only the interviewer and the participant, with an average duration of nine minutes and 29 seconds. Study participants were identified as E1, E2, E3, and so on, until E19.

\section{Data transcription}

The interviews were transcribed in full by the researchers/ interviewers themselves. Each interviewer transcribed each interview that she conducted. There were no external analysts.

\section{Data analysis}

For data analysis, the methodological orientation of Content Analysis, thematic modality, was followed, with the completion of the three recommended steps. The first stage, pre-analysis, was based on an intense and exhaustive reading of the material, with a view to apprehending the data and the particularities of the set. The second stage, material exploration, was based on material exploration, proceeding to identification of categories and grouping of context units. In the third stage, interpretative synthesis, the sections were grouped according to the themes that emerged and organization into thematic units ${ }^{(10)}$. Data analysis was anchored in the approximation, with the theoretical framework of the work process ${ }^{(8)}$ and the object of the study.

From data analysis, two thematic categories emerged: Cooperative behavior of professionals from an oncohematology unit; Composition, characteristics and management of the unit.

\section{RESULTS}

Among the 19 participants, 17 (89.47\%) were female, two (10.53\%) were male, aged between 30 and 57 years old and average age 39.47 years old. Regarding training, 16 (84.21\%) professionals had completed higher education and three (15.79\%) had incomplete higher education. It is noteworthy that 13 professionals $(68.42 \%)$ had some type of complementary training, and among them, 13 had specialization, two (15.38\%) had a master's degree and one (7.69\%) had a doctoral degree. The average training time was 15 years, with experience in oncohematology ranging from one year and two months to 23 years, with an average of five years.

Through analysis of all interviews, two thematic categories emerged: Cooperative behavior of professionals from an oncohematology unit; Composition, characteristics and management of the unit. Such thematic categories bring, in their core, professionals' perceptions about teamwork, as well as their facilitators and hinders, in the oncohematology unit. It is noteworthy that such categories did not include the subcategories. During the process of compiling the categories, the findings emerging in the analysis were grouped by content affinity in these two thematic axes, which included the themes revealed.

Cooperative behavior of professionals from an oncohematology unit reveals the relationship and conviviality of professionals in the oncohematology unit, anchored in teamwork, with a focus on patient care. It shows that participants perceive teamwork through: collaboration; mutual help; cooperation; continuity of work, despite the shift change; valorization of all professional categories; complementarity of knowledge; routine and division of tasks based on collaboration; Communication; interprofessional relationships; unity. This category also includes aspects that facilitate and hinder teamwork.

For the interviewees, collaboration, mutual help and cooperation, regardless of professional category, are elementary principles for carrying out teamwork and give meaning to this type of work. This can be illustrated in the following reports.

Teamwork [...] we really have hands together [...] like, I started medication, the patient stopped by the side, I will see my patient's priorities, but I cannot leave mine colleague [...] without this assistance [...] my colleague's patient is also mine. (E7)

[...] no health professional can work alone [...] besides each one doing their job [...], which is attributed to them, I think that working as a team is in the sense of helping one another [...] at least, here, I think we really have this spirit of cooperation, than, if not, one is always overwhelmed [...]. (E17)

Another meaning attributed to teamwork, by participants, concerns the continuity of others' work based on collaboration, despite the change of work shift. This is exemplified in the following statements.

[...] teamwork in health is continuity [...]. If you didn't have time to do it in the morning, do it in the afternoon, if you didn't have time to do it in the afternoon, it should be done at night, you just don't do it if it's unfeasible [...]. (E9) 
I believe that teamwork is the continuity of the work that is being carried out. Here, in this sector, we manage to have [...] a legal continuity because the morning staff, he speaks the same language as the afternoon staff, who speak the same language as the night staff [...]. We don't look angry at each other for things that should be on your duty and passed to mine. (E14)

Some participants perceive and reveal that all professional categories, which work in oncohematology, are important, regardless, even, whether workers have specific training in health. They indicate the complementarity of knowledge as an important assumption for teamwork.

There are also the cleaning girls that I always try to talk to [...]. I don't have this separation [...]. It is logical that they cannot interfere in the nursing work or us in their work, but it is not because they are not from nursing that I leave them isolated [...]. It is a job that, sometimes, the person considers that it is not so good, but if you have a hospital that is not clean, how will it be [...]? So, I think everyone has their due Worth. (E10)

[...] for us, teamwork is essential. So, there is no use for the doctor to prescribe and the medication is not administered properly. The patient has a complication and the doctor does not know that he has had a complication. It is useless to have an inpatient patient thirty days and not have psychological support, an Occupational Therapy job, not having a physical therapist. (E16)

Still, as to the meanings attributed to teamwork, in the oncohematology unit, the interviewees revealed that, despite the routine and division of tasks, this does not make teamwork impossible, since professionals collaborate with other workers in the carrying out the work. This contributes to work balance and avoids overload.

Teamwork, I think that professionals who are aware of work, of the sector's routine, are always helping each other and we know the needs without even having to sometimes ask [...]. I know that my colleague needs it, so I'm going to offer myself there, I'm going to help, I'm going to help in the bath, I'm going to help in the passage. (E2)

[...] there is the multidisciplinary team [...]; you are not alone with yours [refers to the patient], you help everyone [...]; we share to be more or less the same service for everyone, but not necessarily I work only with these [...] we know what is happening with each patient, everyone has to be aware, we are always talking [...]. (E8)

However, on the other hand, the reports regarding the perception of teams as being specifically that of nursing or the collective work carried out only between nursing and medicine and a desire for this to occur with the other professional categories called attention.

Teamwork? It is a job that [...] multidisciplinary professionals participate in [...] that endeavor. In our case here, our nursing team is a very closed team [...]. A very good group, united [...]. Closed [referring to the nursing team] in the context [...] of union [...]. Closed in a context of needing even the other at the moment that has the greatest difficulty [...]. (E1)
[...] I think that the medical and nursing team is more closely together, and I would like to be able to be closer to the others as well [...]. (E17)

Cooperative behavior of professionals from an oncohematology unit, in addition to revealing the meanings of teamwork, it also contemplates the factors considered facilitators for this work in participants' perceptions.

The non-material instruments of the work process, such as dialogue, adequate communication, good interprofessional relationships and meetings with different workers, are perceived as facilitators as they avoid noise and strengthen interprofessional relationships, which, consequently, contributes to achieve the purpose of the work process.

[...] that facilitates [referring to teamwork] dialogue [...] I think dialogue is interesting in the sense that she knows what we do and that she tries to fit her service into ours and vice versa [...] so, at this point, I think dialogue helps [...]. (E5)

A good relationship between all areas. So, the meetings that we have a meeting here a week, and that goes to the people of physio, the people of psychology, the speech therapist, nurses [...] this contact that we have once a week is important. (E6)

Still regarding the facilitators for teamwork, the referred category shows unity, collaboration and mutual help as aspects experienced in the unit and that facilitate teamwork. There is a synchrony: there is no need to ask for help from the other, because this assistance occurs spontaneously, it is something shared by workers. This can be illustrated in the following statements.

[...] then, I have to have my coffee [...]. In the meantime, the patient can ring the bell and my colleague, who is there, he can go there and supply me, understand? I don't need to go to him and ask if he can replace me, it's automatic. (E1)

[...] our team [...]; we can thank God [...]; we are very united, we are very close [...]. We already have the dynamics to help each other, so, everything is quiet [...] even if the day is running the same now, we can, for instance, "Ah, are you doing this there?", "No!!! So, you can let me go and get the patient there". We try to find out what is the need of the other and how is the other to be able to help. It doesn't happen everywhere. Here is why we managed to develop this among us. (E3)

The health scenario draws attention as a complex and dialectical space, since, on the one hand, the interviewees revealed that dialogue is present and facilitates teamwork, on the other, the failure and lack of communication between workers in daily life, making it difficult for teamwork, including compromising the purpose of the work process.

Lack of communication [...] for me, is the main cause that makes it difficult; sometimes, not being present, sometimes, the times do not match and you are unable to contact physio, you are unable to contact nutritionist. So, this lack of communication, sometimes, it gets in the way. (E6)

[...] perhaps, observing some sign and symptom and not [...] expressing [...] sometimes, for some reason, like, sometimes, the rush of 
the sector, it is, some complication that generated a forgetfulness of that communication. This can also make [...] it difficult. (E7)

Another complicating aspect, which emerged in the speeches, concerns the non-material instruments of the work process, referring to lack of knowledge of assignment of another team worker, to the different types of personality and to the different ways of carrying out the work.

[...] the doctors are going here, they don't know what the nursing service is, so, they want something, they don't know what we go through to be able to make it ready, understand? So, sometimes, it's time for the shift change, they want us to do something [...] and we don't do it, they think we're lazy, understand? [...]. (E5)

It is that, sometimes, you will pass something to the person, the person, he is so skittish, you know that his personality is so skittish for certain things that you are afraid to speak [...]. The person's personality ends up creating a barrier for you to pass on information and they receive it and you in a quiet way. (E14)

Composition, characteristics and management of the unit brings up the assumptions for teamwork from the perspective of the organization and the dynamics of work in the unit, material instruments, capacity building and training, team composition, as well as organizational management, showing that such aspects influence teamwork.

For the interviewees, the fact that the unit is a smaller sector, has a team composed of a smaller number of professionals from different categories depending on the number of beds and the availability of material are aspects that enable communication between workers and understanding of what is the attribution of each one.

It is a small team and we can talk well with each other because the sector is restricted, it is small, it has few patients, and we know exactly the role of each one. (E2)

[...] for being a small sector, that we know every institution and [...] we almost never lack the material [...] we rarely have to go, leave the sector to search, borrow material [...] or that, like this, the nurses try to leave [...] enough material [...] so, I think that makes it a lot easier. (E4)

Participants revealed that professional qualification and training are important aspects, considering the specificity and complexity of patients. They pointed out that the best preparation of workers facilitates teamwork and impacts the improvement of the assistance provided.

The work here is progressive and continuous, we have very good logistics because we have nurses who are specialized [...]. Who are cancer nurses [...]. (E1)

[...] qualification, professional qualification, which is a personal factor, each one seeks to qualify, to qualify, within their area of expertise, so that they can really perform better and better [...] we observe that everyone [...] are concerned about it, to qualify more and more. (E13)
At the same time that some participants reported that the number of professionals and the materials are adequate, on the other hand, others indicated the lack of materials and the deficit in the workforce, which can generate overload. In view of these revelations and those previously presented, it is evident the plurality of perceptions regarding the same aspects in the unit.

[...] it is considered organized [...] as far as possible, [...] with the little things of the people here [...], but sometimes there is a lack of material that gets in the way [...], but usually the we can work well here. There is also the issue of lack of employees [...] is that it gets in the way [...]. (E9)

[...] reasonable staff. At the moment, we have a small deficit of employees, but we still have it and when we have worked with more employees, we realize that we are able to give a better service to patients [...]. (E14)

The lack of psychological support to the team emerged as one of the factors that most attracted attention in this study. As it is a unit in which patients are considered serious and demand extremely strict care, compared to other sectors, this demands more from professionals physically and psychologically, who often have to offer emotional and psychological assistance to patients without having the adequate training for that.

[...] we experience a lot of sad things here, and there is also the thing that the hematological patient always dies [...] so, that somatizes in our heads, sometimes, we get the impression that we work, work, do everything for patients so that, in the end, they die [...] we should have the right to a professional, a psychologist [...]. (E9)

In the sense of being a service for critically ill patients [...], an excessive demand for work and that we sometimes do not even have time to talk to each other in terms of "I am sad because l lost a patient today" [...] there are some points that I think the team [...] is not being assisted. (E16)

In this thematic category, the service management aspect emerged in the speeches. For the interviewees, the fact that the hospital's management institutions do not understand how the work in oncohematology really occurs and do not know the difficulties that professionals face in everyday life makes the work more bureaucratic, permeated by inequalities and conflicts, representing a hindrance for teamwork.

What makes it difficult for us is the relationship we have with the hospital management, with $X$ [referring to an administrative sector] [...] they don't understand what the hospital's routine is [...] they bureaucratize the service [...] they give privileges to one and do not give to the other, this generates antipathy among workers. (E11)

Our team, they are very restricted [...] today, we have a loss of employees [...]; they took the palliative care nucleus from us [...], psychologist, they removed the [...] nutritionist, they removed it! How does a group work without these professionals? Understood? So, I think the hospital, they have to understand the importance of teams. (E16) 


\section{DISCUSSION}

In the interviews, the work process components were revealed, such as workers, material/non-material instruments and purpose ${ }^{(8)}$, as tools that influence teamwork.

The findings bring assumptions for teamwork configured as non-material instruments of the work process, considering teamwork as a complex process that is improved and hampered by a variety of factors ${ }^{(11)}$, such as organization and non-material instruments ${ }^{(12)}$ NOC.

Inter-professional cooperation and collaboration, the articulation of actions and communication are essential to face the fragmentation of work and the construction of interprofessional actions ${ }^{(13-15)}$. Thus, teamwork is linked to professionals' intrinsic and extrinsic behaviors, such as communication, engagement, union and coresponsibility ${ }^{(15)}$. Such elements are present in the daily routine of oncohematology and are perceived as facilitators for teamwork.

In the context in focus, it was identified that the communicational process is effective and contributes to the accomplishment of work and teamwork. However, on the other hand, the results give voice to the need for effective communication, based on dialogue and exchange. This reveals the dialectical, dynamic and complex character of health services. Communication is essential for teamwork, including active, real-time communication while performing procedures and related to patient safety ${ }^{(16)}$. Critical patients, in particular, depend even more on effective interprofessional communication for the quick solution of problems ${ }^{(17)}$, and communication failures are a source of adverse care events ${ }^{(18)}$.

Ignorance of the other's work and the different types of personalities, based on low receptivity, hinder teamwork and make the communication process and professional interaction unfeasible. It is pertinent to highlight that satisfaction results from the recognition and recognition of your work by the other ${ }^{(19)}$. Effective teamwork requires good interpersonal relationships ${ }^{(16)}$.

However, the professionals are still very connected to the specific knowledge of their areas and have difficulties in building an integrated work ${ }^{(20)}$. Perceptions of teams, as being strictly those of nursing, converge with the literature, which found the perspective of teamwork as specific to nursing ${ }^{(15)}$. Stereotypes also influence teamwork, which can be related to nursing, often being passive towards work, being little recognized by other professions $^{(21)}$.

The organization and composition of the unit, from the number of beds, the number of workers in the work process, to the adequate number of material instruments are facilitators for teamwork. The findings converge with the literature, which indicated that the availability of materials and the quantity and quality of professionals are essential for ensuring quality and continuity of care $^{(22)}$. The insufficient quantity or its absence negatively impact the interprofessional relationship ${ }^{(12)}$, compromising teamwork.

In another perspective, the insufficient number of professionals and material resources makes teamwork difficult and generates overload and wear for workers. In fact, the reduced number of professionals is one of the factors related to the increase in adverse events ${ }^{(23)}$, and the work overload influences its quality ${ }^{(24)}$, also considering that cancer patients generate greater work overload than non-cancer patients ${ }^{(25)}$.
Professional qualification and training are facilitators for teamwork, enabling better quality care and patient safety. Literature calls attention to the need for training and the implementation of guides and organizational policies in order to value teamwork and ensure the conditions for its realization ${ }^{(7)}$, contributing to overcome barriers to professional integration ${ }^{(26)}$.

Betting on investment in permanent education means reorienting work processes ${ }^{(27)}$. Professional qualification/training contributes to the development of emotional skills, so that workers know how to deal better with cancer patients and their families ${ }^{(28)}$, being essential in the scenario in focus in this research.

The lack of psychological support and support for the oncohematology team and the finiteness of patients' lives weaken professionals. The demand for care, with different degrees of intervention and involvement of excessive emotional burden, present in the oncological hospital context, leads to fragile interprofessional relationships and even to dissatisfaction and lack of motivation $^{(4)}$. It seems that, at the same time that the assistance to cancer patients mobilizes, in the professionals, several emotions, feelings and support to them and their family, on the other hand, workers tend to avoid the creation of affective bonds to protect themselves from suffering ${ }^{(28)}$.

Literature also portrayed that many professionals who deal with oncology try to leave due to psychological distress, and these departures have repercussions in care, making it limited. Interaction groups are suggested as a way to favor work ${ }^{(28)}$, i.e., interventions that improve quality of work are more effective solutions in the long run $^{(29)}$.

In the oncohematology sector, it is suggested to hold discussions and moments focused on the reflection of multidisciplinary teams, with a view to better coping with situations that generate workers' moral distress ${ }^{(30)}$. Moreover, meetings and discussions with multidisciplinary teams reflect in the reduction of patients treatment time and increase their survival ${ }^{(31)}$.

Another finding, which drew a lot of attention, concerns the performance of management in the service. The testimonies showed the feeling of almost invisibility of work processes developed in the unit's daily life by management agencies, which makes it difficult to carry out work and teamwork.

Literature indicated that, if there is management support, with regard to the needs of professionals, this will contribute to a favorable environment and to appropriate interpersonal relationships ${ }^{(4)}$. Management, which identifies the needs of its professionals and invests in this aspect, builds a compensatory system in which there will be an improvement in quality of service and less problems ${ }^{(29)}$. Managerial and organizational factors can interfere, even, in the quality of collaboration and in the development of interprofessional skills ${ }^{(18)}$ as well as the leadership and the dynamics of the team can influence teamwork ${ }^{(32)}$.

Initially, when the project was conceived, the intention was to hold discussions with the oncohematology workers after the end of the study to debate and reflect on the results, with a view to redefining teamwork in practice. However, this was rendered unfeasible due to the impossibility of professionals to be absent from the unit. Therefore, the results were returned to oncohematology professionals through a folder with information about the theme, the placement of a banner with the results of 
the research as well as the presentation and discussion of results in the unit's three work shifts.

\section{Study limitations}

As a limitation, the reorganization that the sector underwent, close to the period of data collection, related to the decrease in the number of workers on the team and physical change of the oncohematology unit to another space within the hospital, is evident. However, this did not prevent relevant findings from emerging.

\section{Contributions to nursing and health}

It is noteworthy that it has emerged, in the results, that the hospital management institutions do not understand the daily work in oncohematology with its adversities, which weakens teamwork. The complaint of lack of psychological support to professionals reveals the lack of workers in this regard in the face of assistance that generates emotional strain on the team. It is expected that the results will lead the service management to look closely at the unit and visualize its needs, with a view to providing adequate working conditions and strategies for the psychological support of professionals.

\section{FINAL CONSIDERATIONS}

This study made it possible to identify workers' perceptions in a hospital oncohematology unit regarding teamwork. The results showed that communication, collaboration, routine/division of tasks, availability of materials and trained and welcomed workers are essential elements for the existence of solid and teamwork. The specificity and size of the sector facilitates teamwork, contributing to the purpose of the work process to be realized.

Lack of communication, low collaboration, lack of knowledge of the duties of another worker, lack of materials, insufficient number of professionals, work overload, in addition to the lack of psychological support and understanding on the part of management regarding work and the difficulties faced by the team in oncohematology hinder teamwork.

The results brought to light the specificity of the sector, the demand for specialized assistance and the daily work cut out by a very fine line between life and death, generating professional wear and suffering. No matter how hard workers work, the unit does not always have the right conditions for the realization of teamwork.

The theme is not intended to be exhausted, but it is worth noting that the study revealed the need for management to consider the care and psychological support for oncohematology workers as a therapeutic strategy for professionals. We bet on the approximation of management agencies with the daily life experienced in that unit, with a view to understanding the factors that involve work and its workers, which may enable work conditions that favor teamwork with a view to doing in more integrated, articulated and welcoming healthcare.

\section{FUNDING AND ACKNOWLEDGMENT}

We are grateful to the Teaching and Research Management (TRM) of Clinics Hospital of Universidade Federal do Triângulo Mineiro (HC-UFTM).

\section{REFERENCES}

1. Oliveira RM, Silva LMS, Guedes MVC, Oliveira ACS, Sánchez RG, Torres AM. Analyzing the concept of disruptive behavior in healthcare work: an integrative review. Rev Esc Enferm USP. 2016;50(4):690-9. https://doi.org/10.1590/S0080-623420160000500021

2. Zeleníková R, Jarošová D, Plevová l, Janíková E. Nurses' perceptions of professional practice environment and its relation to missed nursing care and nurse satisfaction. Int J Environ Res Public Health. 2020;17(3805):1-10. https://doi.org/10.3390/ijerph17113805

3. Rosen MA, Diaz-Granados D, Dietz AS, Benishek LE, Thompson D, Pronovost PJ, et al. Teamwork in healthcare: key discoveries enabling safer, high-quality care. Am Psychol. 2018;73(4):433-50. https://doi.org/10.1037/amp0000298

4. Silva VR, Velasque LS, Tonini T. Job satisfaction in an oncology nursing team. Rev Bras Enferm. 2017;70(5):1040-7. https://doi. org/10.1590/0034-7167-2016-0422

5. Dirks JL. Effective strategies for teaching teamwork. Crit Care Nurse. 2019;39(4):40-7. https://doi.org/10.4037/ccn2019704

6. Tremblay D, Roberge D, Touati N, Maunsell E, Berbiche D. Effects of interdisciplinary teamwork on patient-reported experience of cancer care. BMC Health Serv Res. 2017;17(218):1-11. https://doi.org/10.1186/s12913-017-2166-7

7. Schmutz JB, Meier LL, Manser T. How effective is teamwork really? The relationship between teamwork and performance in healthcare teams: a systematic review and meta-analysis. BMJ Open. 2019;9(9):1-16. https://doi.org/10.1136/bmjopen-2018-028280

8. Gonçalves RBM. Práticas de saúde: processos de trabalho e necessidades. São Paulo: CEFOR; 1992.

9. Tong A, Sainsbury P, Craig J. Consolidated criteria for reporting qualitative research (COREQ):a 32-item checklist for interviews and focus groups. Int J Qual Health Care. 2007;19(6):349-57. https://doi.org/10.1093/intqhc/mzm042

10. Minayo MC. O desafio do conhecimento: pesquisa qualitativa em saúde. 13th ed. São Paulo: Hucitec; 2013.

11. Salih ZNI, Draucker CB. Facilitators of and barriers to successful teamwork during resuscitations in a neonatal intensive care unit. J Perinatol. 2019;39(7):974-82. https://doi.org/10.1038/s41372-019-0380-3

12. Noce LGA, Oliveira TS, Melo LC, Silva KFB, Parreira, BDM, Goulart BF. Interprofessional relationships of a patient assistance team in critical care. Rev Bras Enferm, 2020;73(4):e20190420. https://doi.org/10.1590/0034-7167-2019-0420 
13. Arruda LS, Moreira COF. Interprofessional collaboration: a case study regarding the professionals of the Care Center for Elderly, Rio de Janeiro State University (NAI/UERJ), Brazil. Interface comum saúde educ. 2018;22(64):199-210. https://doi.org/10.1590/1807-57622016.0613

14. Agreli HF, Peduzzi M, Silva MC. Patient centred care in interprofessional collaborative practice. Interface comum saúde educ. 2016;20(59):905-16. https://doi.org/10.1590/1807-57622015.0511

15. Souza GC, Peduzzi M, Silva JAM, Carvalho BG. Trabalho em equipe de enfermagem: circunscrito à profissão ou colaboração interprofissional? Rev Esc Enferm USP. 2016;50(4):642-9. https://doi.org/10.1590/S0080-623420160000500015

16. Lapierre A, Lefebvre $\mathrm{H}$, Gauvin-Lepage J. Factors affecting interprofessional teamwork in emergency department care of polytrauma patients: results of an exploratory study. J Trauma Nurs. 2019;26(6):312-22. https://doi.org/10.1097/JTN.0000000000000469

17. Kendall-Gallagher D, Reeves S, Alexanian JA, Kitto S. A nursing perspective of interprofessional work in critical care: findings from a secondary analysis. J Crit Care. 2017;38:20-6. https://doi.org/10.1016/j.jcrc.2016.10.007

18. Schwartz ME, Welsh DE, Paull DE, Knowles RS, DeLeeuw LD, Hemphill RR, et al. The effects of crew resource management on teamwork and safety climate at Veterans Health Administration facilities. J Health Risk Manag. 2017;38(1):17-37. https://doi.org/10.1002/jhrm.21292

19. Siqueira ASA, Teixeira ER. Oncological palliative care and its psychic influences in the perception of nurses. Rev Min Enferm. 2019; $23: e-1268$. https://doi.org/10.5935/1415-2762.20190116

20. Miorin JD, Camponogara S, Brutti TB, Ilha AG. Colaboração interprofissional entre as equipes de saúde dos serviços de urgência e emergência: revisão integrativa. Res Soc Develop. 2020;9(2):78922074. https://doi.org/10.33448/rsd-v9i2.2074

21. Mayo AT, Woolley AW. Teamwork in health care: maximizing collective intelligence via inclusive collaboration and open communication. AMA J Ethics. 2016;18(9):933-40. https://doi.org/10.1001/journalofethics.2016.18.9.stas2-1609

22. Leal LA, Soares MI, Silva BR, Chaves LDP, Camelo SHH. Challenges to develop competencies in the hospital framework. Rev Min Enferm. 2018;22:e1099. https://doi.org/10.5935/1415-2762.20180042

23. Macedo TR, Rocha PK, Tomazoni A, Souza S, Anders JC, Davis K. The culture of patient safety from the perspective of the pediatric emergency nursing team. Rev Esc Enferm USP. 2016;50(5):756-62. https://doi.org/10.1590/s0080-623420160000600007

24. Costa DB, Ramos D, Gabriel CS, Bernardes A. Patient safety culture: evaluation by nursing professionals. Texto Contexto Enferm. 2018;27(3):1-9. https://doi.org/10.1590/0104-070720180002670016

25. Silva JB, Moreira SD, Apolinário PP, Vieira APG, Simmelink VLMS, Secoli SR, et al. Nursing workload in a hematology/oncology inpatient unit. Enferm Glob [Internet]. 2017 [cited 2020 Dec 12];48:35-45. Available from: https://revistas.um.es/eglobal/article/view/259151/216831

26. Ben-Arye E, Popper-Giveon A, Samuels N, Mutafoglu K, Schiff E, Omran S, et al. Communication and integration: a qualitative analysis of perspectives among Middle Eastern oncology healthcare professionals on the integration of complementary medicine in supportive cancer care. J Cancer Res Clin Oncol. 2016;142(5):1117-26. https://doi.org/10.1007/s00432-016-2120-9

27. Silva LAA, Soder RM, Petry L, Oliveira IC. Educação permanente em saúde na atenção básica: percepção dos gestores municipais de saúde, Rev Gaúcha Enferm. 2017;38(1):1-8. https://doi.org/10.1590/1983-1447.2017.01.58779

28. Luz KR, Vargas MAO, Barlem ELD, Schmitt PH, Ramos FRS, Meirelles BHS. Coping strategies for oncology nurses in high complexity. Rev Bras Enferm. 2016;69(1):67-71. https://doi.org/10.1590/0034-7167.2016690109i

29. Zaheer S, Ginsburg L, Wong HJ, Thomson K, Bain L, Wulffhart Z. Turnover intention of hospital staff in Ontario, Canada: exploring the role of frontline supervisors, teamwork, and mindful organizing. Human Res Health. 2019;17(66):1-9. https://doi.org/10.1186/s12960-019-0404-2

30. Fruet IMA, Dalmolin GL, Bresolin JZ, Andolhe R, Barlem ELD. Moral distress assessment in the nursing team of a hematology-oncology sector. Rev Bras Enferm. 2019;72(Suppl-1):63-71. https://doi.org/10.1590/0034-7167-2017-0408

31. Atwell D, Vignarajah DD, Chan BA, Buddle N, Manders PM, West K, et al. Referral rates to multidisciplinary team meetings: is there disparity between tumour streams? J Rad Oncol. 2019;63(3):378-82. https://doi.org/10.1111/1754-9485.12851

32. Walton V, Hodgen A, Long JC, Johnson J, Greenfield D. Exploring interdisciplinary teamwork to support effective ward rounds. Int J Health Care Qual Assur. 2020;33(4-5):373-87. https://doi.org/10.1108/JHCQA-10-2019-0178. 